\title{
16. Control of Invaders
}

\author{
D.L. Dahlsten
}

\subsection{Introduction}

Invasions of organisms have been of great concern to those involved in the various aspects of food and fiber production. In many cases, introduced species have been deliberately released, such as most of the plants used in commercial agriculture and the parasitoids and predaceous insects that are used in classical biological control attempts. However, many invaders are accidentally introduced, such as insects and pathogens, and many of these are a threat to commercially important commodities. Of the 444 species of insects and mites listed by Metcalf et al. (1951) as crop pests in the United States, it is estimated that approximately $36 \%$ of them are introductions (van den Bosch 1971). Many applied scientists, pest managers, and growers or producers spend much of their time concerning themselves with controlling pests, many of which are invading species. Usually the well-established invaders are treated as native pests and conventional control techniques are used. On the other hand, some pest management strategies have been developed to deal specifically with invading species and these are eradication and classical biological control. In many cases, the biology and ecology of the invaders is poorly understood and as a result the control programs are poorly conceived. This is particularly true with eradication programs.

Federal and state institutions have developed around these strategies to deal with invaders. The Division of Biological Control at the University of California 
at Berkeley and Riverside deal primarily with insect problems as do most of the agencies. There are international agencies as well, such as the Commonwealth Institute for Biological Control. In the United States, the U.S. Department of Agriculture, Agricultural Research Service has a biological control program and operates a number of national and international laboratories. A listing of all biological control programs and laboratories (state and federal) is compiled annually (Coulson and Hagan 1984).

Eradication programs are planned and funded in part by the Animal and Plant Health Inspection Service (APHIS) of the U.S. Department of Agriculture. This agency is responsible for detection, quarantine, and the development of eradication techniques for invading species. The individual states oftentimes have a comparable agency for the same activities and usually fund part of the programs as well. The vigor with which eradication is pursued varies from state to state. The California Department of Food and Agriculture (CDFA) is an unusually vigorous and efficient agency in its response to invading species. For example, in 1984, the CDFA was involved in seven eradication programs (apple maggot, gypsy moth, Japanese beetle, cotton boll weevil, Mexican fruit fly, oriental fruit fly, and the Caribbean fruit fly). The approach taken by the agencies responsible is similar with each insect and this will be discussed below. Many of these programs have stirred considerable public controversy because they are largely based on the use of chemical insecticides.

The federal government, through APHIS, maintains a quarantine program to keep out a number of potential plant pests. The CDFA also maintains an inspection service and border stations on major highways entering California as part of their program. Most of the plant pests intercepted are insects. For example, from 1 October 1978 through 30 September 1979, APHIS intercepted 18,644 plant pests at the various ports of entry in the United States (Anonymous 1981). Of these, 14,002 (75\%) were insects. In California, numerous interceptions are made at the border stations each year. The number of interceptions has risen in recent years but it is not certain if this is due to greater vigilance on the part of CDFA staff or to more insects and other pests entering the state because of increased movement. The mobility of modern society and the amount of travel by air, sea, and land unquestionably provides more opportunity for insects and pests to move from place to place. Modern jets are capable of moving pests around the world within hours, so the potential for invaders is even greater. Introductions could also be a function of pest population density. For example, the increased movement of gypsy moth into California was no doubt partly related to the recent (1980-1982) outbreaks in the eastern United States. The total numbers of live and dead gypsy moths (of various stages) intercepted at border stations and discovered as a result of county quarantine inspections since 1980 are shown in Table 16.1 .

An interesting, though largely unanswerable, question is, What proportion of the invaders are actually intercepted? Suffice it to say that if the federal or California quarantine and inspection programs get $10 \%$ of the organisms actually coming in, they are doing well. The quarantine probably discourages people from bringing in potentially infested items, so, on balance, such programs are 
Table 16.1. Total numbers of gypsy moth individuals intercepted by California state border stations and discovered by county quarantine inspections in California, 1980-1985

\begin{tabular}{lrrrrrr}
\hline \multicolumn{1}{c}{ Year } & 1980 & 1981 & 1982 & 1983 & 1984 & 1985 \\
\hline Border Stations & 21 & 47 & 146 & 267 & 348 & 375 \\
County Inspection & 112 & 210 & 198 & 200 & 109 & 84 \\
$\quad$ Total & 133 & 257 & 344 & 467 & 457 & 459 \\
\hline
\end{tabular}

Source: Alan Clark and Dick Brown, California Department of Food and Agriculture, Sacremento, California, personal communication.

worthwhile. The next question is, what becomes of all the pests that are introduced? Obviously most of them die out, or perhaps remain at undetectable levels for several years before dying out. Those that are detected will often become the object of an eradication program.

There are great philosophical differences between the proponents of eradication and those proposing biological control. These have been discussed at length by Perkins (1982) and will not be discussed here. However, this controversy can be put into proper perspective if such differences are understood at the outset. There are some other approaches to dealing with invading species, such as habitat management: either make the habitat undesirable for the invader or make the habitat desirable for the natural enemies of the invaders. These will be discussed below.

\subsection{Biological Control}

As with any definition of a field as broad as biological control, there is considerable controversy as to what biological control really encompasses (DeBach 1964a). To some, natural control of any population by biotic agents is considered naturally occurring biological control. However, the classical definition defines the field of endeavor as practiced by many agencies and this involves the activities of humans. Biological control is the importation of natural enemies (parasitoids or protelean parasites, predators and pathogens) to control introduced insect or plant pests. A contemporary definition of the field includes not only the importation activities but also basic studies of population dynamics, insect behavior, etc. In addition, there are also programs to control native pests by introduction of natural enemies or by augmentation and conservation of native natural enemies. The modern or contemporary definition of biological control is the study, importation, augmentation, and conservation of natural enemies. Biological control does not include any of the autocidal approaches such as the sterile male technique and the use of pheromones or the development of pest-resistant plants. There are many publications in the field, ranging from basic publications on theories of population regulation to reports of biological control attempts. There are also several textbooks that describe the many phases of biological control, from theory to quarantine and importation procedures to 
case histories of many biological control programs (DeBach 1964a; Huffaker 1971; Huffaker and Messenger 1976; van den Bosch et al. 1982).

An important component of biological control efforts is the control of invaders. The rationale is that a non-native species introduced into an area can be brought under control if its "ecology" is understood. This usually involves determining the country of origin of the invading species and then going to that country and searching for the pests' natural enemies. The natural enemies when found are then imported, put into quarantine to eliminate secondary parasitoids, and then released or put into an insectary for mass rearing. In agriculture the invading pests are usually attacking a deliberately released invading plant. The natural enemies that are released then can also be considered invaders. In forestry, the invading pest species are usually attacking native trees.

Almost all of the work in biological control has been done with insects and mites that are parasitoids or predators, and with phytophagous insects. Little has been done with pathogens as biological control agents. Pathogens such as Bacillus thuringiensis are being used primarily as microbial insecticides, and this is a rapidly developing area of pest control. There are examples of biological control work with exotic pathogens such as the inadvertent introduction of a nucleopolyhedrosis virus for control of the European spruce sawfly, Diprion hercyniae (Hartig), in Canada (McGugan and Coppel 1962).

It is difficult to get an estimate of the percentage of success versus the number of attempts at releasing parasitoids and predators. In part this is due to poor record keeping, but it is also due to inadequate sampling and evaluation procedures. Many times this is a result of the length of time necessary for the establishment and buildup of the natural enemies. By 1971, biological control had been attempted against 223 species of insects and some degree of success has been recorded for over half of these species. In the Coccoidea (scale, mealybugs, etc.), there has been some degree of success with 50 of 64 species attempted (78\% successful). With all the other insect groups, some degree of success has been attained with 70 of 159 species (44\% successful) (DeBach et al. 1971). There have been some startling successes and several of these will be discussed below. The biological control strategy gained considerable impetus in the late 1800 s with the successful control program against the cottony cushion scale in California (see below). Since that time there have been many introductions, primarily of beneficial insects to control arthropod and plant pests worldwide. A review of 80 years of literature on these introductions showed introductions against arthropod pests in 12 orders and 74 families and against plants in 16 families (Clausen 1978). This, of course, does not include any of the unpublished introduction attempts.

There have been many successes and to 1976 Laing and Hamai (1976) listed 327 examples of partial to complete successes of biological control of insects and 57 examples of plants for every location into which importation has occurred. DeBach (1964a) drew some general conclusions regarding the various successes to 1964; of 107 species controlled, 41 were coccidae (Homoptera), 21 Lepidoptera, 18 Coleoptera, and 16 were Homoptera other than Coccidae. He found with these species that control was usually due to one dominant natural 
enemy and that parasitoids were four times more successful than predators as control agents. DeBach concludes that the successes were as common in temperate regions as in the climatically less variable tropical and subtropical areas. Biological control has proven to be a viable control strategy in North America as illustrated by the case histories described below.

\subsubsection{Cottony Cushion Scale: Icerya purchasi Maskell}

The biological control project against the cottony scale in California established biological control as a valid pest control technique. The history of biological control antedates this project but the project is considered by most as the milestone for biological control. The scale was believed to have been introduced near Menlo Park, California, around 1868 and initially fed upon Acacia. Its native home was thought to be Australia. By 1887, the scale was threatening the growing California citrus industry. At the recommendation of C.V. Riley, who was Chief of the Division of Entomology in the U.S. government at the time, a search for the natural enemies of the cottony cushion scale in its native home was conducted. Albert Koebele went to Australia in August of 1888 to begin the search. It is interesting that W.G. Klee, the California State Inspector of Fruit Pests, had arranged independently with Frazer Crawford in Australia to send natural enemies of the scale to California. Crawford sent some parasitic flies, Cryptochetum iceryae (Williston) (Cryptochetidae), to Klee in 1888 and these flies were liberated in San Mateo County in 1888 before Koebele sailed for Australia (Doutt 1954). This fly is still an effective parasite of the scale in several counties of the San Francisco Bay Area in addition to some areas in southern California.

Koebele was successful in his search and sent close to 12,000 individuals of Cryptochetum to California. Later, in 1888, he discovered the coccinellid, Rodolia (Vedalia) cardinalis (Mulsant) and from November of 1888 to January of 1889 he sent in a total of 129 of these ladybird beetles. D.W. Coquillet received the beetles and placed them under a tent on an infested orange tree in Los Angeles. In April the tent was removed and the beetles began moving to other scale-infested trees. By the middle of June, Coquillet and the owner of the orange grove, J. W. Wolfskill and his foreman, Alexander Craw, had distributed 10,555 beetles to 228 different orchardists (Doutt 1964). The distribution of the beetles continued from one grower to another and by the end of 1889 many of the growers were reporting that the beetles had literally cleaned their trees of the scale. The rail shipments of oranges from Los Angeles County alone jumped from 700 to 2000 car loads in one year (Doutt 1954). The cost of this fantastic success was about $\$ 1500$.

The two natural enemies are still effective in controlling the cottony cushion scale throughout California. The ladybird beetle, because of the spectacular success in southern California, is referred to more often than the parasitic fly. However, it has been found that in the desert areas the beetle is dominant and displaces Cryptochetum. On the coast, the reverse is true and the fly displaces 
Rodolia. The two coexist in interior areas (DeBach et al. 1971). Since the California experience, the ladybird beetle has been used successfully in 25 other countries where complete control has been achieved and in four countries where there has been a substantial degree of control. The underlying biological and ecological explanations for the success of these programs are not really known. It remains the goal of biological control workers to find these explanations and then to use this information to develop further the biological control technique.

\subsubsection{Olive Scale: Parlatoria oleae (Colvee)}

The olive scale became a major pest of olives in California around 1934. It also became a pest of a number of deciduous fruit crops as well as ornamental trees and shrubs. By 1961, the scale had spread throughout the San Joaquin and Sacramento Valleys and into scattered sites in southern California (DeBach et al. 1971).

On olive, the first instars, or crawlers, of the second generation tend to settle and develop on the fruit. This means that relatively low scale densities in the first generation can result in considerable fruit infestation in the early fall. This is important to the olive growers since scale-discolored fruits are subject to cullage. A biological control program to be successful would have to reduce the scale to extremely low densities.

An intensive biological control program was initiated in 1949 and a small parasitic wasp, Aphytis maculicornis (Masi) (Aphelinidae) was introduced from Egypt. From 1951 to 1953 an effort was made to collect parasites from olive scale throughout its range of distribution. Several species of parasites were obtained and released including four "strains" or sibling species of Aphytis that were morphologically indistinguishable from $A$. maculicornis. The "strains" were distinct biologically, however, and were therefore reared and released separately (Doutt 1954; Hafez and Doutt 1954).

The "Persian strain" of A. maculicornis, which was obtained from Iran and Iraq and colonized in 1952, was found to be the only parasite giving some degree of control. Efforts were concentrated on this parasite and over 27 million individuals were released between 1952 and 1960 at numerous sites in 24 counties in California (Huffaker et al. 1962). Rosen and DeBach (1976) eventually classified the "Persian strain" as a sibling species, A. paramaculicornis.

This parasite was very effective and reached parasitization rates of at least $90 \%$ on the olive scale. However, since only one scale on a fruit may cause it to be culled, these drastic reductions in scale were not enough. The solution was therefore not an economical one for the growers. Higher rates of parasitization were not possible as the parasites could not tolerate the hot, dry summers of the Central Valley. It was also found that the unusually low fall or spring temperatures reduced the overall effectiveness of this parasite (Huffaker et al. 1962).

The decision was made to look for additional natural enemies of the olive scale. In 1957, P. DeBach rediscovered Coccophagoides utilis Doutt (Aphelinidae) in Pakistan on olive scale on apple (van den Bosch et al. 1982). This parasite had been discovered in the early 1950s but since it has a complex life 
cycle and is difficult to rear, the colony was lost. $C$. utilis became established and showed promise to improve the control of olive scale. It was colonized and mass-reared and over four million parasites were released at 170 sites in 24 of California's counties from 1962 to 1964 (Kennett et al. 1966). This parasite was also collected from heavily infested trees in the field and distributed to other sites. This is similar to the type of distribution that took place with the Vedalia ladybird beetle and cottony cushion scale (see above). The use of field "insectary trees" is an efficient and economical way to raise and subsequently distribute natural enemies.

The introduction of $C$. utilis proved to be an effective addition and in combination with $A$. paramaculicornis resulted in complete control of the olive scale. The development of $C$. utilis is well synchronized with olive scale development and averages about $40 \%$ parasitization on the two generations of scale each year. However, it probably could not have controlled the scale alone (DeBach et al. 1971). Since C. utilis was able to survive the summers without undue losses and contribute to scale mortality in the fall, it was an ideal complement to $A$. paramaculicornis.

The olive scale project took much longer and was not nearly as spectacular as the cottony cushion scale project but it was every bit as successful. Also, a number of important contributions were made to biological control methodology. It was shown that multiple introductions of parasites could be successful and that natural enemies could attain an acceptable level of economic control in a commercial crop. The importance of a broad search for natural enemies throughout the range of the host was demonstrated. The existence of "biological strains" or sibling species and their comparative efficacy in controlling the host was found, showing, in part, the importance of taxonomy to the field of biological control.

\subsubsection{St. Johnswort or Klamath Weed: Hypericum perforatum $L$.}

Invading plants that are determined to be pests have also been the subject of biological control attempts. Worldwide to 1976 there have been 57 partial to complete successful attempts at biological control of plants (Laing and Hamai 1976). Most attempts have been made with phytophagous insects but there is increasing interest in the use of pathogens (Andres et al. 1976). There have been two startling successes: the control of prickly pear in Australia with a cactus-feeding moth, Cactoblastis cactorum (Berg), which was imported from Argentina, and the control of St. Johnswort in California. The latter of these major successes is the topic of this section.

Biological control of weeds involves rigorous feeding tests with candidate insects to ensure that any introduced species will not feed on economically important crops or ornamental plants. The control of St. Johnswort is an example of a properly and carefully conducted biological control project.

St. Johnswort (Hypericaceae) is a perennial native of Europe but it has spread throughout many of the temperate areas of the world. It is considered a major plant pest in several areas including northwestern North America. The plant has two other common names in the western United States. In Washington and 
Oregon it is called goat weed. In California it is called Klamath weed because it was first reported in the vicinity of the Klamath River in the northern part of the state around 1900.

This plant not only crowds out useful range plants but also has undesirable effects on certain range animals. Those animals with unpigmented skin become very sensitive to sunlight. The white skin areas of the animals become irritated; eventually sore, scrubby patches form on the hide. The plant also acts as an irritant in the mouth, and animals appear to suffer discomfort while drinking water (Holloway 1964). The end result is that the animals do not do as well as other animals because they cannot maintain a normal appetite and do not gain weight.

Biological control against $\boldsymbol{H}$. perforatum was initiated by the Australians in 1920. The initial search efforts were concentrated in England. On completion of starvation tests three chrysomelid beetle species in the genus Chrysolina were released. Only $C$. hyperici (Forster), a leaf feeder, became established but the rate of increase and dispersion was slow. The search was extended to southern France and after further testing two beetles from France became established, C. quadrigemina (Suffrian) and Agrilus hyperici (Creutzer) (Buprestidae), a root feeder. In all, eight insect species were introduced into Australia (Andres et al. 1976). Although good control has been achieved in some localized areas, overall the programs can be rated only partially successful. However, the program in Australia turned out to be very important to the California biological control attempts that were started in 1944.

Klamath weed had spread to 30 counties in California and was occupying approximately 2 million acres of useful rangeland by 1944 (Holloway 1964). The war in Europe in 1944 made importation from France impossible, so arrangements were made with the Australian government to bring in the two Chrysolina species and Agrilus. The first problem was to get the insects in phase with the seasons in the Northern Hemisphere. This was solved with the aestivating Chrysolina adults by applying fine sprays of water which resulted in the beetles becoming active within 3 weeks after their arrival and thus synchronized with the seasons in California. Problems were encountered with the Agrilus root borers and it was decided to import them from the Northern Hemisphere after the war. Further starvation tests were done with the two species of Chrysolina and the releases started in California in 1945 and 1946.

The two Chrysolina species became established and importations were no longer necessary after 2 years. It was found that $C$. quadrigemina was increasing much faster than $C$. hyperici. After three generations in the field it was possible to collect thousands of beetles for redistribution from the original location where 5000 beetles were released (Holloway 1964). In 1950, three million adult beetles were collected from this site and redistributed. The success of $C$. quadrigemina is due to its better synchronization with the growth phases of the plant. Both Chrysolina species are brought out of aestivation by autumn rainfall, but $C$. quadrigemina requires less rain than $C$. hyperici and therefore starts feeding and egg laying sooner when the plants are more suitable as food (Holloway 1964). 
The root borer, Agrilus, was sent to California from Europe in 1947 for further feeding studies. By 1950 releases were made and the root borer was established. The borers were overwhelmed by $C$. quadrigemina in the colonization areas but borers are still present in certain locations.

Within 10 years after the release of Chrysolina the Klamath weed was reduced to less than $1 \%$ of its former abundance and was removed from California's list of noxious weeds (Huffaker and Kennett 1959). The Chrysolina beetles have been released in British Columbia in Canada, New Zealand, South Africa, Chile, Hawaii, and Washington, Oregon, Idaho, and Montana in the northwestern United States with varying degrees of success (Holloway 1964; Andres et al. 1976; Laing and Hamai 1976).

\subsubsection{Winter Moth: Operophthera brumata (L.)}

The winter moth is a well known pest of fruit and deciduous trees in Europe and is an example of an invading species that poses a threat to indigenous forest hardwoods as well as to introduced fruit trees in North America. The winter moth, a geometrid, was introduced, presumably from Europe, and was first reported in 1949 on the south shore of Nova Scotia after being confused for some years with the spring cankerworm, Paleacrita vernata Peck (McGugan and Coppel 1962). In a span of 10 years the damage in the oak forest due to the winter moth was calculated to be 26,000 cords per year in two counties. If the moth would have continued unchecked the losses would have seriously affected the forest economy in Nova Scotia (Embree 1971a).

The winter moth control project was initiated in 1954. Because at that time the moth was considered only a minor pest of shade trees and apple orchards and since it dispersed slowly, it was possible to institute a biological control program. If the moth had been recognized 10 to 15 years later when paper and hardwood mills were in existence, a chemical insecticide would most certainly have been used (Embree 1971a).

From 1955 to 1960 six species of parasites (three tachnids and three ichneumonids) were introduced from Europe. Four of the parasites did not become established but a tachinid fly, Cyzenis albicans (Fallen), and a ichneumonid wasp, Agrypon flaveolatum (Gravely), became established within 3 years. To assist in the establishment of the parasites, large numbers of host larvae were collected and reared in areas where release was desired and the parasites were obtained from this material (Embree 1971a).

There are 63 known parasites of the winter moth (Wylie 1960) but only six were selected for release. They were apparently selected based on abundance and when it appeared that two were going to be successful, further releases of other species were discontinued to avoid potential competition. By 1961 the winter moth had become a minor pest due to the action of the two introduced parasites. A nuclear polyhedrosis virus was found in 1961 and is now generally present over the range of the winter moth in eastern Canada. It has caused the decline of at least two infestations (Embree 1971b).

The winter moth project is an example of how a control project should be 
conducted. The population dynamics of the moth had been studied in England for several years (Varley and Gradwell 1968), and by Embree (1971a) in Canada just prior to the release of the parasites. Embree made his initial parasite releases at one point on the edge of his main study area. This enabled him to study the efficacy of the parasite as well as its dispersal ability. After 3 years, in 1958, the parasites were released in other locations in Nova Scotia (Embree 1971a). Detailed life table analysis showed that prior to the parasite introductions, the lack of early instar larval hatch synchronization with bud burst and subsequent starvation was the key factor in the dynamics of the winter moth. In 1958 parasitism was $8 \%$ but by 1960 it was $72 \%$ and in 1961 the winter moth population collapsed. Embree (1971a) was therefore able to demonstrate that parasitism alone was responsible for the collapse of the winter moth populations.

The two parasites that were established are compatible and supplementary in that $C$. albicans is the most efficient at high densities and can react rapidly to host increases. On the other hand, A. flaveolatum is more efficient at low host densities as it oviposits directly on the host. Both species can survive at low host densities. $C$. albicans, which oviposits near feeding damage and not on the host directly, can better survive multiparasitism because it develops more rapidly within the host (Embree 1971a).

The winter moth still occurs throughout Nova Scotia and in isolated pockets of New Brunswick and Prince Edward Island (Embree 1971b) . It is not now considered to be a major pest of hardwood forests in the area. It is occasionally a pest in apple orchards and populations are controlled with chemical insecticides. The winter moth is well synchronized with bud burst on apple. On occasion outbreaks occur in abandoned apple orchards but these are of short duration. The two parasites reach high densities in these apple orchards but generation survival is perhaps higher due to synchronization with apple bud burst.

The winter moth is poorly controlled in Europe even though there are many parasites. This may be due to hyperparasites, which reduce the effectiveness of parasites, or because of competition between the parasites (Pschorn-Walcher et al. 1969). Another explanation for the ineffectiveness of $C$. albicans in England has been posed by Hassell (1978). Beetles and shrews can cause high mortality of winter moth pupae in the soil, because $C$. albicans pupates in the soil. It too may be subject to such predation. Winter mortality of the winter moth, and presumably $C$. albicans, is much lower in Novia Scotia. As a result winter moth population levels at equilibrium are 10 times higher in England than in Nova Scotia because of the greater parasite winter mortality in England.

Although this project demonstrated the importance of careful documentation in biological control, we are still not certain why the two compatible parasitoids were so successful in Nova Scotia but not in Europe. The synchronization of the larvae with bud burst may be one of the factors in the hardwood forests, but the lack of hyperparasitism, predation, and competition may actually be the most important factor. As with the olive scale (see above), the importance of two supplementary parasites is demonstrated. Also, a case can be made for careful selection and introduction of a few parasites rather than multiple species 
releases and selection of the fittest. However, since $C$. albicans and A. flaveolatum do not effect good control in Europe, would they have even been selected for use elsewhere? In all successful biological control cases to date, serendipity has certainly played a role. The future should see increased evaluation on all biological control introductions.

\subsubsection{European Spruce Sawfly: Diprion hercyniae (Hartig)}

The European spruce sawfly is another example of an invading species attacking a native forest tree. This defoliator was considered a major threat to spruce forests in eastern Canada in the 1930s. In 1931 over 2000 square miles of forest was defoliated in the interior of the Gaspe Peninsula of Quebec. In the following years, $D$. hercyniae was found in increasing numbers in New Brunswick and further west in Quebec (McGugan and Coppel 1962). Concern for the forest economy in the region led to one of the largest and subsequently most successful biological control programs in Canada.

Arrangements were made to collect cocoons of $D$. hercyniae in Europe to rear for parasites and subsequent release in Canada. However, D. hercyniae and a closely related species, D. polytomum (Hartig), were so uncommon in Europe that collectors turned to collecting cocoons of other sawflies (D. frutetorum, D. pallidus, D. virens, D. pini, D. similis, D. abieticola, Neodiprion sertifer, Pachynematus scutellatus, and Lygaeonematus abietinus) that were known to be parasitized by the parasites of $D$. hercyniae and D. polytomum (McGugan and Coppel 1962). Between 1933 and 1951, 27 parasite species numbering 890 million individuals were released in the field. Of these 882 million were the eulophid wasp Dahlbominus fuscipennis (Zett.). Initially there was great encouragement about the recovery of $D$. fuscipennis and the Belleville, Ontario, Biological Control Institute developed a highly successful propagation program to facilitate the distribution of the parasites (McGugan and Coppel 1962).

The other two most commonly released parasites were a tachinid fly Drino bohemica (Mesn.) and an ichneumonid Exenterus amictorius (Panz).

The success of this effort shows that a multiple species release program can be successful. Three species of parasites gained considerable importance at high sawfly densities, Dahlbominus fuscipennis, Exenterus amictorius, and E. confusus (McGugan and Coppel 1962). By 1942 sawfly populations were beginning to decline due to parasite activity but also due to a nucleopolyhedrosis virus that was discovered in 1938 . It is speculated that the virus was inadvertently released with the parasites. The virus disease spread and it was one of the first times that virus disease was recognized as being important in the control of insect populations.

The virus, according to Bird and Elgee (1957), caused the sawfly populations to crash before the full potential of the parasites was realized. They felt, however, that the parasites might have been able to bring the populations under control without the disease. By 1945 the sawfly was not considered to be a threat to forests of eastern Canada and by 1958 it was no longer considered to 
be an economically important forest insect (Neilson et al. 1971). The release program was terminated after 1951. It is interesting that two other species of introduced parasites (Drino bohemica and Exenterus vellicatus (Cash.) are important in maintaining the sawfly at low population levels (Bird and Elgee 1957). As the European spruce sawfly became less and less important, attention was focused on native sawflies and many of the parasites were also tested against seven species of Neodiprion and Pikonema alaskensis (Rob.). Approximately 900,000 parasites were released between 1937 and 1951 to control these sawflies.

The effectiveness of the virus and parasites was demonstrated once again in the 1960s in New Brunswick. For 3 consecutive years (1960-1962) one of the study areas was sprayed with DDT for the spruce budworm. As a result sawfly densities were reduced to the lowest level ever recorded and the parasites and virus were for all purposes eliminated from the area. Sawfly populations began to recover and within five generations after spraying stopped, reached densities of the outbreak years. Parasitism was evident three sawfly generations after spraying ceased and parasitism increased from 12 to $37 \%$ in the six following sawfly generations. The virus appeared in the seventh post-spray generation and by the second generation of 1966 the sawfly populations were reduced to abundances found during pre-spray years (Neilsen et al. 1971).

The European spruce sawfly program is only one of 20 agricultural and forest insect and eight plant biological control programs promoted by Agriculture Canada (Commonwealth Agriculture Bureau 1962 and 1971). In spite of the successes, interest in biological control lessened and in 1955 there was a definite change in policy. This may have been due, in part, to the increasing importance of chemical insecticides in pest control at that time. The responsibilities of the staff at the Institute for Biological Control at Belleville, Ontario were reduced in 1955 and in about 10 years this highly successful unit was closed. During the 1960s biological control efforts reached a low point in Canada, but since then emphasis on this approach has increased markedly (Hall 1981).

\subsection{Habitat Management}

Another approach to pest control is through habitat management. Prior to the advent of the modern chemical approach, cultural techniques for controlling pests were commonly practiced in agriculture and with many crops this is still true (Pimentel et al. 1978). Interest in this approach has increased since the 1970 s, when it was realized that chemicals were not a panacea. As with biological control, habitat management would not be a technique chosen to combat invading species as a first choice. The approach does offer some possibilities for making a particular habitat less vulnerable to invaders. However, not nearly as much work has been done with this compared to biological control techniques.

There are two ways that habitat modification can be approached in both agriculture and forest systems. The first is habitat modification aimed at encouraging, enhancing, or conserving natural enemies of invading species and this is closely related to activities in biological control. The second is habitat 
modification to make an agricultural or forest community less susceptible to invading pest species and is a preventative approach.

\subsubsection{Habitat Modification to Encourage Natural Enemies}

Many of the modern agricultural practices such as the removal of competing plants and trees, use of pesticides, large monocultures, use of fertilizers, irrigation, and planting of uniform genotypes have created simplified environments that are now susceptible to invading species but are unfavorable to natural enemy activity. The trend in modern forestry with respect to fiber production is also toward habitat simplification and is likely to result in problems similar to those seen in agriculture (Dahlsten 1976).

There has been relatively little research done on habitat management to provide alternate food sources, shelter, breeding sites and other ecological requisites for natural enemies. This area of study, and the ecological theory underlying the approach, have been reviewed by Altieri (1983) and van den Bosch and Telford (1964). Adding diversity to agricultural environments by growing crop plants together in polycultures may provide the necessary ecological requisites for some natural enemies. Diversity in the form of undesirable plants may also be important. Although many plants compete with the crop plants and may harbor insect pests or diseases, there also are positive attributes of non-crop plants (Altieri 1983). Non-crop plants can be the source of food for natural enemies either by providing alternate prey or pollen or nectar. Insects, such as aphids, living on non-crop plants may produce honeydew and this, too, can be used as food by various parasites. Some non-crop plants may provide refuges for natural enemies while others may attract natural enemies to an area. It has been shown that parasitization of corn earworm eggs by small wasps (Trichogramma sp.) can be increased by spraying fields with extracts of a plant (Amaranthus sp.) (Altieri 1983). Other examples of such non-crop plants enhancing the biological control of specific crop pests are given by Altieri and Letourneau (1982). In forestry, it has been shown that native parasites of an invading species, the European pine shoot moth, Rhyacionia buoliana (Denis and Schiffermuller), had increased longevity and fecundity due to herbaceous plants, some of which are considered noxious weeds (Syme 1975). The two parasites, Exeristes comstocki Cressan and Hyssopus thymus Girault, have been effective at times in depressing shoot moth populations and their success depends, in part, on the availability of an energy source. Nectar from the wild flowers provides this energy source and Syme (1975) feels that the status of certain plants as noxious weeds should be reviewed, particularly when they occur in the confines of pine plantations.

In forest communities ground cover and dead trees (snags) may provide protection, roosting sites, feeding sites, and nesting sites for generalist vertebrate predators, mostly small mammals and birds. For the most part, the importance of vertebrate predators in controlling pest arthropods has been little studied (van den Bosch and Telford 1964; Dickson et al. 1979). Larvae of the gypsy moth, Lymantria dispar (L.), an invading species, feed primarily at night but 
during the day retire to cool, moist secluded places to rest and eventually pupate. Vegetation cover on the forest floor is important to the gypsy moth as well as to small mammals and arthropods that feed on the gypsy moth. Vegetative cover on the forest floor has been correlated with predator efficacy and as a result gypsy moth defoliation is seldom severe where there is good undergrowth and abundant litter (Bess et al. 1947).

Artificial structures have been used to encourage and increase natural enemies of pests. Attempts have been made to create nesting shelters for arthropods such as Polistes wasps which are predators of some agricultural pests, and artificial nesting sites for ants, Formica rufa L., in forest environments in Europe (van den Bosch and Telford 1964). Nesting boxes designed to encourage cavitynesting insectivorous birds have been used extensively in the forests of Europe (Bruns 1960) and more recently in the western United States (Dahlsten and Copper 1979). It has been demonstrated that bird populations can be increased rather readily with nest boxes; however, the documentation of the impact of the birds on selected forest insect populations is sparse. Some ecologists consider birds to be inverse density-dependent factors and that birds are important in maintaining some forest pests at low densities.

\subsubsection{Habitat Modification to Reduce Vulnerability of Habitats to Invaders}

Pest control by modifying agricultural or forest habitats to make them less susceptible to pests, some of which may be invading species, has its roots in ecology and in recent years has received increased attention. The idea that diversity leads to stability in ecological systems is appealing to many applied and basic ecologists. In agriculture the fields can be made more diverse by leaving noncrop plants or by using polycultures as compared to the clean monocultures so commonly used in agriculture today in developed countries. Polycultures are common and have been used for many years in less-developed countries (Altieri 1983). There are a number of examples of the benefits of multicropping systems in preventing insect outbreaks (Altieri and Letourneau 1982). Diversity in agriculture does not mean there will be no pest problems but a review of 150 experiments by a number of researchers is encouraging (Risch et al. 1983). Approximately $53 \%$ of the insect pests in these experiments were reduced in their incidence in diversified systems whereas only $18 \%$ of the pest insects increased in the diverse systems.

The forest, by comparison to agricultural ecosystems, is an already diverse habitat. However, recent efforts in forestry are to simplify forests for efficiency in production of timber (Dahlsten 1976). The forester and forest pest manager can, through various silvicultural procedures, effect changes in species composition, age composition, and stocking (density) of forest stands. Graham (1956) states that, in theory, mixed species, mixed-age, non-overstocked stands are least subject to damage by insect and disease pests. This is the basis of silvicultural control and a way that forests could be protected from invading insects and diseases.

In the past, the role of phytophagous species has always been viewed as 
negative in forest ecosystems. However, Mattson and Addy (1975) have given a fresh perspective to the ecological role of insects in forest ecosystems. They argue that, in fact, some insects play a positive role in maximizing primary production in forest ecosystems. In addition, there is increasing evidence that some forest insects occur on poor sites, where trees are overstocked (overcrowded) or where trees are overmature and declining from old age (Dahlsten and Rowney 1983; Mattson and Addy 1975). Finally, it appears that many tree species are adapted to disturbances for their existence and insects, along with fire, windstorms, and other disturbances, play important roles in succession and the dynamics of forest communities (Mattson and Addy 1975; Smith 1976; McLoed 1980).

The gypsy moth, Lymantia dispar, is a well-publicized invader from Europe whose larvae feed on a wide variety of tree species but prefer oaks, particularly white and chestnut oaks. The moth was initially introduced in North America in Massachusetts and has been moving north, south, and west since 1869. Currently there are active eradication and control programs for the gypsy moth in a number of southern states and in the west-British Columbia, Washington, Oregon, and California. It appears that the gypsy moth will eventually spread over much of North America. A closer look at the effects of the gypsy moth on trees and forests is necessary. In the eastern hardwood forests the moth alters the species composition on some sites by selective mortality (Campbell and Sloan 1977). Damage was most severe on weaker trees in the lower crown classes. Subsequent outbreaks of the gypsy moth have been less damaging on these sites. Others have also associated the gypsy moth with disturbances and poor sites (Bess et al. 1947; Houston 1979). Disturbances due to fire and logging have hampered forest development on some sites and have favored the preferred food of the gypsy moth. Urbanization has also created additional susceptible sites (Houston 1979). Recent outbreaks in New England have occurred in stands with low moisture availability. Trees on dry ridges or drained sandy soils are often the preferred hosts, whereas stands on moist sites are faster growing and contain mixtures of preferred and non-preferred hosts. Slower growing and/or exposed trees on ridges, because of bark texture, for example, provide more refuges for pupation than faster growing, straight trees on moist sites. (Houston 1979).

\subsection{Eradication}

The idea of totally eliminating a species, a pest, from an area has had great appeal to the pest-control profession. The basic simplicity of removing the problem completely and not having to worry about management is a panacea to some but unrealistic to others. The debate is not new and is renewed everytime an eradication program is proposed. As early as the beginning of this century Congress appropriated funds to eradicate the European corn borer, Ostrinia nubialis (Hubner) (Cox 1978).

Technological innovations in recent years have given renewed hope to pest 
managers that eradication of certain pests can become a reality. The continuing development of chemical pesticides and application strategies is no doubt the greatest impetus since chemical pesticides are the most commonly used technique in eradication programs. Rapid development in the field of insect attractants, pheromones, etc. has facilitated the trapping of adults of invading species. Effective trapping is the necessary component in the early discovery of invading potential insect pests. In the state of California attempts are made to trap 14 insect species on an annual basis. (Table 16.2.)

One of the important developments among the eradication arguments was the sterile insects approach. Knipling had great success eradicating the screwworm fly Cochliomyia hominivorax (Coquerel), a pest of cattle from the small island of Curacao. Knipling subsequently became the most prominent spokesperson for eradication or total pest management (Perkins 1982). The screwworm fly project probably generated too much optimism among applied entomologists for the application of the sterility approach to eradicating pests (Newsom 1978). According to Knipling (1978) the possibliity of eradication should be continually re-evaluated based on new technological developments as they became available.

Eradication as a concept is defined in a number of different ways by applied entomologists. The most realistic definition is one given by Newsom (1978):

Eradication is the destruction of every individual of a species from an area surrounded by naturally occuring or man-made barriers sufficiently effective to prevent reinvasion of the area except through the intervention of man.

Because of the differences in definition of the term, the evaluation of the success of many projects is not clear. By the dictionary definition of eradication there is not a single example of an insect pest being eradicated. There have been some successful programs if modifications are made as to a prescribed area and a specific period of time (Newsom 1978). The successful programs are those where the invading species has been detected relatively soon after the introduction and the suspected area of infestation is relatively small. In California, for example, there have been 27 successful eradication programs against nine insect species. Three of the insects have been eradicated twice (Khapra beetle, Japanese beetle, and the Mediterranean fruit fly) and one (Oriental fruit fly) has been eradicated 15 times (Frankie et al. 1982).

There have been several large-scale eradication attempts against well-established invading species. It is questionable whether the eradication approach should really be attempted against this category of pests. There has been an extremely high failure-to-success ratio and in addition these projects are very costly in terms of money and manpower (Newsom 1978). Since chemical pesticides are almost always used, other problems such as human health and environmental side effects are also magnified by comparison to the smaller projects. Examples of controversial large-scale programs are the boll weevil Anthonomus grandis (Boheman) and the imported fire ant Solenopsis saevissima richteri (Forel) eradication projects, both in the southern United States. 
Table 16.2. 1984 California statewide trap counts for 14 insects on the dates with highest trap density and lowest trap density

\begin{tabular}{lcc}
\hline & \multicolumn{2}{c}{ Statewide Trap Counts } \\
\cline { 2 - 3 } \multicolumn{1}{c}{ Species Trapped } & High & Low \\
\hline Mediterranean fruit fly & 38,843 & Jan. 21, 1984 \\
Oriental fruit fly & 12,693 & 32,697 \\
$\quad$ Melon fly & 32,455 & 10,559 \\
Gypsy moth & 14,426 & 361 \\
Apple maggot & 15,396 & 94 \\
Japanese beetle & 7348 & 338 \\
Cotton boll weevil & 157 & 6316 \\
Europeanpine shoot moth & 206 & 30 \\
European corn borer & 8815 & 22 \\
Mexican fruit fly & & 5210 \\
$\quad$ Carribbean fruit fly & 6688 & \\
Peach fruit fly & 76 & 6573 \\
Khapra beetle & 137,103 & 0 \\
Comstock mealy bug & & 62,200 \\
$\quad$ Total & &
\end{tabular}

Source: Del Clark, California Department of Food and Agriculture, Sacramento, California, personal communication). 9

\subsubsection{Characteristics of Eradication Programs}

The approach to eradication has become highly institutionalized, no doubt due to the extremely high costs in terms of money and human resources. The federal agency in the Department of Agriculture is APHIS, and in the states usually a department of agriculture, as in California. Most eradication programs, whether large or small, have much in common and they can be characterized generally. The generalizations that follow, however, are intended to apply to recent relatively localized invasions or attempts to prevent invasions.

The first line of defense against invading species in detection and exclusion. The federal government maintains inspection services at ports of entry throughout the United States. In California there are border stations on all major highways entering the state. Workers have a list of various undesirable pests that they look for or they confiscate certain plant material, fruit, or anything that might be infested with various pests. For the gypsy moth in California, moving vans coming from potentially infested areas must have a certificate that the contents of the van were inspected at the time of loading, otherwise the entire van must be unloaded and inspected. In addition, the addresses of those moving into California from areas infested with gypsy moth are put on a computer and usually new arrivals will have a gypsy moth trap placed on their property. Certainly these procedures discourage the public from trying to bring 
potentially infested material into the state, but the question is, What percentage of the material is caught at the borders or the ports of entry and is this costly exercise economically justified?

Detection of invaders by using pheromones or chemical attractants is a rapidly developing field. Trapping is becoming more and more common throughout the United States as traps become more efficient and new traps become available. Early detection, although important, perhaps could also lead to many more eradication programs for some insects that could never become established. There is an increasing tendency to initiate an eradication program based on the trapping of adults alone, however, it is important in many cases that a second life-state (eggs, larvae, or pupe) be found before initiating a program that may not be necessary. In California, this has been done with the gypsy moth but there has been pressure from the Gypsy Moth Science Advisory Committee to base the decision to treat on the trapping of adult males alone. No doubt many pests have invaded parts of the United States on many occasions in the past and certainly prior to the use of the traps. Some pests such as the cereal leaf beetle Oulema melanopus (L.) and the citrus blackfly Aleurocanthus waglumi (Ashby) are examples of pests that became firmly established over large areas prior to discovery (Newsom 1978). At some point serious thought must be given to the whole approach. The seven concurrent eradication programs in California in 1984 may be only the beginning of a continuing and potentially escalating approach by state and federal agencies to attempt the elimination of invading potential plant pests. The decision to eradicate should be considered very seriously as will be discussed below.

Quarantine is another form of exclusion. The threat of quarantine can force other states or countries into programs of inspection, fumigation, and eradication that otherwise might not be undertaken. The threat of quarantine on California fruit by several states and Japan no doubt expedited and expanded the aerial malathion-bait application for Mediterranean fruit fly in 1981 and 1982.

Once the decision has been made to eradicate, the next decision is the selection of the means of eradication and how the material is to be applied. Almost always a chemical pesticide is selected because they are fast acting and easily applied by aerial means. The use of aircraft in urban environments also avoids contact with uncooperative homeowners. However, ground application may be a better choice even though much more material is applied because there is more control over where the chemical is placed. Logistically, ground application is not easy in many cases but if small localized areas are to be treated it is feasible. This has been done in California with the gypsy moth for 4 years (1980-1984) with carbaryl. Ground application of malathion bait spray was also used for the Mediterranean fruit fly along with fruit stripping and the release of sterile flies in California in 1980. However, some non-sterile flies were accidentally released and the infestation exploded in Santa Clara County and then aerial application was used in 1981 and 1982. It appeared that the initial program was successful but the release of the non-sterile flies necessitated a change in strategy because of the extent of the infestation.

The Mediterranean fruit fly is an interesting example of an insect that has 
been successfully eradicated from several locations in the United States since 1929. Although both ground and air applications of several different chemicals and Malathion bait sprays have been used, the projects have all been successful. The bait traps used for the Med-fly are not very efficient and it could be with this insect as with others, that populations are present but at such low levels as to be undetectable. Since experience with most insecticides and baits has shown that they are rarely, if ever, $100 \%$ effective, how can every eradication program be successful? It suggests that perhaps with some insects there are temporary extensions of range and these invading populations die out from other causes. Sparse insect populations may die out from natural causes or from failure to find mates, and with plant diseases the amount of inoculum may become so reduced that host resistance and environmental influences are sufficient to prevent infection from persisting (Smith 1933). Undoubtedly, many undetected introductions of insects and diseases do not result in establishment because of these factors. Further, the overkill that is common in so many eradication programs may be unnecessary. Once population abundance is reduced the population may not persist because of the natural causes mentioned above. Surely more research on invading insects would help answer some of these questions.

Scientific evaluation of eradication projects is impossible as check plots cannot be used since the goal is total eradication. Also, sparse populations are extremely difficult to work with. All eradication projects involve a great amount of guess work and since information cannot be obtained on the insect in the habitat being invaded, the programs start at the beginning each time. There is little, if any, accumulation of knowledge on these insects. Most often the control techniques are selected based on performance against dense outbreak populations in areas that can be substantially different from the habitat being invaded. The choice of carbaryl for gypsy moth eradication is a good example of this. Carbaryl is used on dense gypsy moth populations in the eastern mixed hardwood forests. The urban areas in California where the gypsy moth has been trapped are very different and are much warmer. The temperature causes the larvae to hatch earlier and over an extended period of time in California (California Department of Food and Agriculture, unpublished data). Larval hatch was determined from very few egg masses but the question of spray timing must be considered as a result. In California a few of the indigenous egg masses were caged in the field to determine timing. With so little information it is difficult to tell if the spray has been timed correctly or not. Further, there is no way to determine why the insects are eliminated. Factors such as weather, suitable hosts, and larval hatch synchronization with bud burst must be considered as possibilities for the ability of a population of the gypsy moth to sustain itself in an area. Again, the assumption is that a chemical, carbaryl is this case, which is rarely $100 \%$ effective at high-level populations, is as effective at low-level populations.

The selection of the chemical is also arbitrary. Using the same evaluation procedures it appears that a microbial insecticide, Bacillus thuringiensis, is equivalent to carbaryl for gypsy moth control, yet in California the Department 
of Food and Agriculture will not use Bacillus except in areas where label restrictions prevent the application of carbaryl. Using the same non-scientific criteria for eradication success, it appears that Bacillus was very effective in Washington and Oregon programs in 1984.

It can be argued that there is a disproportionate amount of money spent on eradication compared to what is spent on monitoring, research, or, for that matter, control projects. Although some chemical monitoring is done by the Calfiornia Department of Food and Agriculture in California, there is little, if any, biological monitoring. The chemical monitoring consists of soil, air, water, and vegetation analysis for residues of the chemical being used. Biological monitoring should be a search for any potential side effects. Aquatic organisms should be sampled before and after treatments as should soil organisms. Certain species that are known to be disrupted by chemical sprays should also be sampled. Many of the homopterans such as diaspine scales, white flies, mealybug, and aphids could be excellent "index" species as well as some phytophagous mite species. Pollinators should also be monitored on these projects. In addition to the monitoring, the eradication projects offer unique opportunities for research.

If only a small percentage of the money devoted to the eradication projects were used for short-term research associated with the application, much could be learned. A larger percentage of the money should be used for long-term research considering the apparent importance of the invading species. The lack of both short- and long-term research is one of the major shortcomings of these programs. This is undoubtedly part of the reason that eradication projects are generally biologically and ecologically unsound in addition to being costly and possibly uneconomical in the long run.

The few short-term studies that have been done indicate that at the very least investigations of potential side effects should be a regular part of all eradication programs. Following the start of the aerial application of malathion-bait spray for the Mediterranean fruit fly (Med-fly) in Santa Clara Valley in 1981 there were numerous calls from homeowners to the California Department of Food and Agriculture (unpublished) on increases of aphids, white flies, mealybugs, etc. As a result, in 1982, the California Department of Food and Agriculture funded a series of studies to look for side effects. The Department is to be commended for undertaking this first-of-its-kind program. The results showed there were both positive and negative effects of the bait spray in the areas studied.

One study focussed on the ice plant scale, Pulvinariella mesembryanthemi (Vallot) and $P$. delotti (Gill), an introduced pest along highways which is the object of a biological control program in part of the treated areas (Washburn et al. 1983). The balance of this system shifted to favor the scale or the natural enemies depending on the frequency and seasonal timing of the application. The effect was therefore mixed, favoring the pest sometimes and sometimes not. In another study, it was found that a diverse group of arthropods were killed by sprays and that aphid and white flies were higher in the spray zone 
as compared with unsprayed areas, indicating an effect on the natural enemies of these homopterens (Troetschler 1983).

In a third study in Stanislaus County, increases in several scale species on olive and citrus were documented in the treated areas as this was attributed to the destruction of natural enemies (Ehler and Endicott 1984). It was also found that a mealybug and two scale species were not affected by the treatment while one scale on olive was actually supressed by the bait spray.

A fourth study showed the bait spray killed a variety of insects, particularly aphids, on live oak, walnut, and Monterey pine (Dahlsten, unpublished). Populations of scale and aphids on California bay and a scale on Monterey pine were lower in the treated areas, while two species of white flies increased on California bay in the treated areas. From all of these studies there can be little question that the Malathion bait sprays kill a wide variety of non-target insects, and that in some cases the potential exists for secondary outbreaks of insects that are also not desirable to homeowners.

Environmental disruptions due to one eradication program were inadvertently documented in southern California as the eradication zone included an area that had been under study as part of a biological control program (DeBach and Rose 1977). In 1973 an eradication program for the Japanese beetle was attempted in San Diego County with carbaryl, chlordane, and dicofol. The woolly white fly had been the subject of a successful biological control program on citrus and several other pests were also under good biological control at the start of the Japanese beetle eradication program. Within a year after eradication attempts were started, woolly whitefly, citrus red mite and purple scale were causing serious damage to citrus in the eradication zone. This is the best documented example of the potential for disruption by chemical eradication programs, clearly the decisions to use chemical pesticides in eradication efforts should not be taken lightly. Many of the eradication programs occur in urban areas since these are the primary sites of introduction. Of 30 successful eradication programs in California listed by Frankie et al. (1982), all but five were in urban environments. Since the general public has developed very strong environmental concerns over the past 15 years, most communities are not eager to be sprayed with chemicals or to have helicopters flying overhead. Citizens have also learned to use the legal system to try to stall or halt eradication programs. The response by federal and state agencies has been to develop smooth public relations operations and to use their legal arm very effectively to avoid any delays in treatment applications. In California, for example, the Department of Food and Agriculture tries to convince the general public that even though there is relatively little scientific information available they are pursuing the correct course. There is little local or citizen involvement and science advisory committees normally support the course of action desired by state officials. These advisory committees supposedly give the projects scientific credibility and they are used precisely in this way.

Since very little money is put into research or evaluation each eradication program becomes a highly institutionalized goal-oriented program. The biology 
and ecology of the target pest and the efficacy of the treatment become secondary to public relations, and organization of the project becomes an end in itself. The information to the public is geared to portraying the invader as an important pest and simplistic economic analyses are used to show how great the losses will be. The agencies insist on a single narrow viewpoint rather than an open, honest appraisal of the problem.

\subsubsection{Criteria for Eradication Decision}

The decision to attempt eradication of a pest should not be made lightly and there are several factors that should be seriously considered before embarking on a program. Since most of the programs are in densely populated areas and usually involve the use of chemical pesticides, the potential human health hazards of such campaigns must be considered first and foremost. Although barely considered in past programs, potential environmental disruptions should be evaluated thoroughly. DeBach (1964b) suggests several additional aspects of eradication of a pest that should be considered before initiating a program.

The first is a careful economic analysis of the cost as compared to the returns and savings that would result from the attempted eradication. The cost of the 1981-1982 Med-fly eradication program in California was approximately 150 million dollars. The gypsy moth programs in California have cost between onehalf and one and one-half million dollars annually. These are both very different examples since one is potentially a pest of agriculture and the other of urban shade trees. The cost of eradication should also be weighed against the ease of reintroduction. The Med-fly, although an important pest of fruit in other countries, is controlled or managed in the same manner as other fruit pests in these countries. The same would no doubt be true in Calfiornia and other parts of the United States. In fact, many of the fruit pest control programs that are already in place may be sufficient for the Med-fly too. It may also be true that the Med-fly is incapable of permanent establishment in most parts of the U.S. due to the pest control activities for other insects as well as climate and other environmental factors. The economic analyses that were done assumed that the Med-fly would be a pest of many fruits in California and did not take into consideration any of the external costs such as the creation of new pests or the elimination of competing pests, human health effects, etc. The same type of economic analyses are done for each pest. The gypsy moth, for example, was assumed to be a pest of the mixed conifer forests in California as well as urban shade trees, chapparal, and agriculture (fruit trees).

The costs of these programs are largely borne by the taxpayers but the beneficiaries of the program are agriculture, forestry, etc. The taxpayers would benefit in the case of the gypsy moth if it were to be kept out of the urban areas. As pointed out above, the urban areas are usually the points of introduction and in many cases bear the brunt of the cost as well as exposure to the pesticides for potential agricultural pests. From an economic perspective it may be far cheaper in the long run to try eradication on an extremely limited basis for some insects but to incorporate others into the pest management pro- 
grams if and when they become pests. Good biological and ecological research would help to resolve the economic threats that are posed by many of the potential pests.

A second issue is to look for any conflicts of interest in the eradication program. The example used by DeBach (1964b) is yellow star thistle. This weed is detrimental to the cattle industry but a benefit to the bee industry. There are other examples that could be drawn from phytophagous insects such as the gypsy moth. As has been shown, some phytophagous insects may have a positive influence on net primary productivity in the forest (Mattson and Addy 1975). Other positive aspects may be the displacement of known pests by the invading species or changes in the plant community that may be desirable. The gypsy moth could conceivably displace the California oak worm, Phryganidia californica (Pack), in urban areas and although the gypsy moth has a broader host range than the oak worm the end result may be swapping one pest for another at no additional cost. Foresters may find the gypsy moth a positive influence since the black oak in California and red alder and willow in Oregon and Washington are desired hosts. Although the gypsy moth feeds on conifers at high population levels, it may result in reducing the number of hardwoods in mixed conifer stands and save the foresters the money that they would normally spend on herbicides to control the hardwoods.

The relative potential danger of the new pest must be evaluated. As can be seen from the discussion above, the gypsy moth cannot be considered nearly as dangerous as the Med-fly, and every invading plant pest poses a somewhat different hazard. Well-planned research programs would help to resolve the potential threats of invaders.

The ease with which an invader can be eradicated should be considered carefully. Those species that escape detection and become well established and widely distributed should be taken off the eradication list. Localized invasion of pests could be the subject of eradication efforts but then effective traps must be available as well as control techniques that are near $100 \%$ effective on lowlevel populations. In addition, the control chosen should be the least disruptive to the environment and not a danger to human health. There are very few invading species for which all these criteria can be met. Since it is impossible to evaluate eradication efforts scientifically, the ease of eradication may never be known anyway. There are so many factors involved in the successful invasion of an area that it is only circumstantial evidence if an invader does not appear in the detection traps a year or two after a treatment of an area. With the gypsy moth in Michigan, it was not certain if low-level survival from eradication attempts or reinfestation from the eastern United States was the reason for the eventual establishment of this invader (Morse and Simmons, 1978, 1979). It was concluded that a policy of spraying when defoliation was visible was the least costly economically and environmentally.

The availability of alternative control strategies should be evaluated for each invader. It appears that certain types of invading species, for example, the Homoptera, are more amenable to biological control than other species. Eradication of the California red scale in the Fillmore area of southern California 
was attempted for many years and then considered a failure (DeBach, 1964b). A successful biological control program is now in existence in this area. The woolly whitefly is another example of a chemical eradication program that failed for which biological control was a successful alternative (DeBach and Rose 1976, 1977). The decision to attempt biological control for the Japanese bayberry whitefly, Parabemisia myricae (Kuwana), in California was based on the success of this approach with the woolly whitefly, in addition to the high cost of chemical eradication due to the widespread distribution of this whitefly in California (Frankie et al. 1982). However, this program has not been successful as yet. This project demonstrates that it is possible to select alternative strategies for dealing with invading species. The gypsy moth program in Michigan is an example of another alternative to eradication (Morse and Simmons 1978).

The last important attribute to be evaluated is the case of recolonization. Species that have already successfully invaded parts of the United States should not be the subjects of eradication programs in other areas of the country. Four of the programs in California were conducted against insects in this category: the Japanese beetle from the eastern United States; the gypsy moth from the east, Michigan, and possibly Oregon as of 1984, the apple maggot from Oregon; and the boll weevil from Arizona. These programs seem destined to failure even if the eradication attempts are successful. Recolonization from bordering states seems almost inevitable, consequently the high costs of eradication cannot be justified. Species that cannot be detected easily are also good candidates for recolonization. Other species such as the fruit fly come in infested fruit, often because people have fruit in their luggage when traveling.

Although there are no simple answers as to when to attempt eradication, the criteria discussed above should be an important part of the decision-making process. Alternatives to eradication are available and in the long run these may be economically and environmentally less costly. In the future there must be a better evaluation of the need for eradication, more consideration of environmental and health effects, ongoing efforts to evaluate the worth of the effort, and the institutionalization of the eradication response should be de-emphasized.

\subsection{Conclusions}

Introduced organisms have in many cases created problems for commercial agriculture and forestry. Those organisms that have become well established and/or widespread in their distribution are usually treated with conventional pest control techniques. However, two approaches have been designed by pest control specialists for dealing specifically with introduced organisms and these are biological control and eradication. There are other possibilities such as habitat modification to either favor the natural enemies of introduced organisms or to make the environment unfavorable for the proliferation of the introduced species.

Philosophically and ecologically the two dominant approaches are completely different. Biological control is a more environmentally compatible strategy that 
will keep introduced species at population densities that do not cause economic damage when it is successful. The goal is not to eliminate the invading species. Eradication, on the other hand, is designed to eliminate the invading species totally.

Eradication programs for invading species are highly institutionalized, very costly, and usually involve the use of toxic chemicals. Most of these programs are in urban areas and there has been increasing concern about the use of chemicals in densely populated regions. The eradication programs are usually surrounded by considerable controversy.

The approach to be taken with respect to invading species, be it biological control, eradication, or habitat management, should be evaluated carefully. Much more emphasis needs to be placed on biological and ecological research of invading species so that the decision on a course of action can be made with an increasing wealth of information. More emphasis must be placed on using techniques that have long-term economic benefit and those that are not environmentally disruptive.

\subsection{Acknowledgments}

I thank my colleagues L.E. Caltagirone, D.L. Rowney, J.W. Lownsbery, M.C. Whitmore, and S.H. Dreistadt for thoughtful, constructive reviews and help in gathering information. I also thank Ms. Karen Branson and Ms. Nettie Mackey for typing and editing.

\subsection{References}

Altieri MA (1983) Agroecology. Division of Biological Control, University of California, Berkeley

Altieri MA, Letourneau DK (1982) Vegetation management and biological control in agroecosystems. Crop Protect 1:405-430

Andres LA, Davis CJ, Harris P, Wapshere AJ (1976) Biological control of weeds. In: Huffaker CB, Messenger PS (eds), Theory and Practice of Biological Control. Academic Press, New York, pp 481-499

Anonymous (1981) List of intercepted plant pests from October 1, 1978 through September 30, 1979. USDA, APHIS publication 82-7

Bess HA, Spurr SH, Littlefield EW (1947) Forest site conditions and the gypsy moth. Harvard Forest Bull 22

Bird FT, Elgee DE (1957) A virus disease and introduced parasites as factors controlling the European spruce sawfly, Diprion hercyniae (Htg.) in central New Brunswick. Can Entomol 89:371-378

Bruns H (1960) The economic importance of birds in forests. Bird Study 7:193-208

Campbell RW, Sloan RJ (1977) Forest stand responses to defoliation by the gypsy moth. For Sci Monogr 19

Clausen CP (1978) Introduced parasites and predators of arthropod pests and weeds: a world review. USDA Agricultural Research Service, Agriculture Handbook No 480

Commonwealth Agricultural Bureau (1962) A review of the biological control attempts against insects and weeds in Canada. Technical Communications Bulletin No 2 
Commonwealth Agricultural Bureau (1971) Biological control programs against insects and weeds in Canada, 1959-1968. Technical Communications Bulletin No 4

Coulson JR, Hagan JH (eds) (1984) U.S. biological control programs using natural enemies against insects, weeds and other pests. USDA Agricultural Research Service, Agricultural Research Service Biological Control Documentation Center, Beltsville, Maryland. Document No 00061

Cox HC (1978) Eradication of plant pests-pros and cons. Bull Entomol Soc Am 24:35.

Dahlsten DL (1976) The third forest. Environment 18:35-42

Dahlsten DL, Copper WA (1979) The use of nesting boxes to study the biology of the mountain chickadee (Parus gambeli) and its impact on selected forest insects. In: Dickson JG, Conner RN, Fleet RR, Kroll JC, Jackson JA (eds), The Role of Insectivorous Birds in Forest Ecosystems. Academic Press, New York, pp 217-260

Dahlsten DL, Rowney DL (1983) Insect pest management in forest ecosystems. Environ Manage 7:65-72

DeBach P (ed) (1964a) Biological Control of Insect Pests and Weeds. Reinhold, New York

DeBach P (1964b) Some ecological aspects of insect eradication. Bull Entomol Soc Am 10:221-224

DeBach P, Rose M (1976) Biological control of woolly whitefly. Calif Agric 30(5): 4-7

DeBach P, Rose M (1977) Environmental upsets caused by chemical eradication. Calif Agric 31(7):8-10

DeBach P, Rosen D, Kennett CE (1971) Biological control of coccids by introduced natural enemies. In: Huffaker CB (ed), Biological Control. Plenum Press, New York, pp 165-194

Dickson JG, Connor RN, Fleet RR, Jackson JA, Kroll JG (eds) (1979) The Role of Insectivorous Birds in Forest Ecosystems. Academic Press, New York

Doutt RL (1954) An evaluation of some natural enemies of the olive scale. J Econ Entomol 47:39-43

Doutt RL (1964) The historical development of biological control. In: DeBach P (ed), Biological Control of Insect Pests and Weeds. Reinhold, New York, pp 2l-42

Ehler LE, Endicott PC (1984) Effect of malathion-bait sprays on biological control of insect pests of olive, citrus and walnut. Hilgardia 52:1-47

Embree DG (1971a) The biological control of the winter moth in eastern Canada by introduced parasites. In: Huffaker CB (ed), Biological Control. Plenum Press, New York, pp 217-226

Embree DG (1971b) Operophtera brumata (L.), winter moth (Lepidoptera: Geometridae). Biological Control Programmes Against Insects and Weeds in Canada, 1959-1968. Commonwealth Institute of Biological Control, Trinidad, Technical Communication No 4, pp 167-175

Frankie GW, Gill R, Koehler CS, Dilly D, Washburn JO, Hamman P (1982) Some considerations for the eradication and management of introduced pests in urban environments. In: Battenfield SL (ed), Proceedings of Symposium on the Imported Fire Ant, June 7-10, 1982, Atlanta, Georgia. US Environmental Protection Agency and USDA, Animal, Plant Health Inspection Service, pp 237-255

Graham SA (1956) Forest insects and the law of natural compensation. Can Entomol 88: 44-55

Hafez M, Doutt RL (1954) Biological evidence of sibling species in Aphytis maculicornis (Masi) (Hymenoptera, Aphelinidae). Can Entomol 86:90-96

Hall RH (1981) A new approach to pest control in Canada. Canadian Environmental Advisory Council, Ottawa, Report No 10

Hassell MP (1978) The Dynamics of Arthropod Predator-Prey Systems. Princeton University Press, Princeton, New Jersey

Holloway JK (1964) Projects in biological control of weeds. In: DeBach P (ed), Biological Control of Insect Pests and Weeds. Reinhold, New York, pp 650-670 
Houston DR (1979) Classifying forest susceptibility to gypsy moth defoliators. U S Department of Agriculture Handbook 542

Huffaker CB (ed) (1971) Biological Control. Plenum Press, New York

Huffaker CB, Kennett CE (1959) A ten-year study of vegetation changes associated with biological control of Klamath weed. J Range Manage 12:69-82

Huffaker CB, Kennett CE, Finney GL (1962) Biological control of the olive scale, Parlatoria oleae (Colvee), in California by imported Aphytis maculicornis (Masi) (Hymenoptera: Aphelinidae). Hilgardia 32:541-636

Huffaker CB, Messenger PS (eds) (1976) Theory and Practice of Biological Control. Academic Press, New York

Kennett CE, Huffaker CB, Finney GL (1966) The role of an autoparasitic aphelinid, Coccophagoides utilis (Doutt), in the control of Parlatoria oleae (Colvee). Hilgardia 37:255-282

Knipling EF (1978) Eradication of plant pests-pro. Bull Entomol Soc Am 24:44-52

Laing JE, Hamai J (1976) Biological control of insect pests and weeds by imported parasites, predators, and pathogens. In: Huffaker CB, Messenger PS (eds), Theory and Practice of Biological Control. Academic Press, New York, pp 685-743

Mattson WJ, Addy ND (1975) Phytophagous insects as regulators of forest primary production. Science 190(4214):515-522

McGugan BM, Coppel HC (1962) A review of the biological control attempts against insects and weeds in Canada. Part II. Biological control of forest insects 1910-1958, pp 35-216. Commonwealth Agricultural Bureau, Farnham Royal, England

McLoed JM (1980) Forests, disturbances and insects. Can Entomol 112:1185-1192

Metcalf CL, Flint WD, Metcalf RL (1951) Destructive and Useful Insects, 3RD edit. McGraw-Hill, New York

Morse JG, Simmons GA (1978) Alternatives to the gypsy moth eradication program in Michigan. Great Lakes Entomol 11:243-248

Morse JG, Simmons GA (1979) Simulation model of gypsy moth introduced into Michigan forests. Environ Entomol 8:293-299

Neilson MM, Martineau R, Rose AH (1971) Diprion hercyniae (Hartig), European spruce sawfly (Hymenoptera: Diprionidae). Biological Control Programmes Against Insects and Weeds in Canada, 1959-1968. Commonwealth Institute for Biological Control, Technical Communication No 4, pp 136-143

Newsom LD (1978) Eradication of plant pests-con. Bull Entomol Soc Am 24:35-40

Perkins JH (1982) Insects, Experts and the Insecticide Crisis. Plenum Press, New York

Pimentel D, Krummel JK, Gallahan D, Hough J, Merrill A, Schreiner I, Vittum P, Koziol F, Back E, Yen D, Fiance S (1978) Benefits and costs of pesticide use in US food production. Bioscience 28:772, 778-783

Pschorn-Walcher H, Schroder D, Eichhorn O (1969) Recent attempts at biological control of some Canadian forest insect pests. Commonwealth Institute of Biological Control Tech Bull 11:1-100.

Risch SJ, Andow D, Altieri MA (1983) Agroecosystem diversity and pest control: data, tentative conclusions and new research directions. Environ Entomol 12:625-629

Smith DM (1976) Changes in eastern forests since 1600 and possible effects. In: Anderson JF, Kaya HK (eds), Perspectives in Forest Entomology. Plenum Press, New York, pp 3-20

Smith HS (1933) The efficacy and economic effects of plant quarantine in California. University of California Agricultural Experiment Station, Berkeley, Bulletin 553, 276 $\mathrm{p}$

Syme PD (1975) The effects of flowers on the longevity and fecundity of two native parasites of the European pine shoot moth in Ontario. Env Entomol 4:337-346

Troetschler RG (1983) Effects of malathion bait sprays used in California to eradicate the Mediterranean fruit fly, Ceratitis capitata (Weidemann) (Diptera: Tephritidae). Environ Entomol 12:1816-1822 
van den Bosch R (1971) Biological control of insects. Annu Rev Ecol System 2:45-66 van den Bosch R, Messenger PS, Gutierrez AP (1982) An Introduction to Biological Control. Plenum Press, New York

van den Bosch R, Telford AD (1964) Environmental modification and biological control. In: DeBach P (ed), Biological Control of Insect Pests and Weeds. Reinhold, New York, pp 459-488

Varley GC, Gradwell GR (1968) Population models for the winter moth. Symp R Entomol Soc Lond 4:132-142

Washburn JA, Tassan RL, Grace K, Bellis, E, Hagen KS, Frankie GW (1983) Effects of malathion sprays on the ice plant insect system. Calif Agric 37(1-2):30-32

Wylie HG (1960) Insect parasites of the winter moth, Operophtera brumata (L.) (Lepidoptera: Geometridae) in western Europe. Entomophaga 5:111-129 